\title{
A review of corporate goals of No Net Loss and Net Positive Impact on biodiversity
}

\author{
Hugo J. Rainey, Edward H. B. Pollard, Guy Dutson \\ Jonathan M. M. Ekstrom, Suzanne R. Livingstone \\ Helen J. Temple and John D. Pilgrim
}

\begin{abstract}
Increased recognition of the business case for managing corporate impacts on the environment has helped drive increasingly detailed and quantified corporate environmental goals. Foremost among these are goals of no net loss (NNL) and net positive impact (NPI). We assess the scale and growth of such corporate goals. Since the first public, company-wide NNL/NPI goal in 2001, 32 companies have set similar goals, of which 18 specifically include biodiversity. Mining companies have set the most NNL/NPI goals, and the majority of those that include biodiversity, despite the generally lower total global impact of the mining industry on biodiversity compared to the agriculture or forestry industries. This could be linked to the mining industry's greater participation in best practice bodies, highprofile impacts, and higher profit margins per area of impact. The detail and quality of present goals vary widely. We examined specific NNL/NPI goals and assessed the extent to which their key components were likely to increase the effectiveness of these goals in benefiting biodiversity and managing business risk. Nonetheless, outcomes are more important than goals, and we urge conservationists to work with companies to both support and monitor their efforts to achieve increasingly ambitious environmental goals.
\end{abstract}

Keywords Biodiversity, corporate social responsibility, mitigation hierarchy, net positive impact, no net loss

This paper contains supplementary material that can be found online at http://journals.cambridge.org

\section{Introduction}

ffective management of corporate biodiversity impacts $\mathrm{C}_{\text {is increasingly being recognized as central to solving }}$ environmental crises (e.g. TEEB, 2010). Following a proliferation of vague 'environmentally friendly' labels (Lavallée \& Plouffe, 2004), specific and quantified corporate environmental goals are increasingly common: for example,

Hugo J. Rainey (Corresponding author), Edward H. B. Pollard, Guy Dutson, Jonathan M. M. Ekstrom, Suzanne R. Livingstone, Helen J. Temple and John D. PILGRIM The Biodiversity Consultancy, 3E King's Parade, Cambridge, CB2 1SJ, UK. E-mail hugo.rainey@thebiodiversityconsultancy.com

Received 11 June 2013. Revision requested 15 July 2013

Accepted 22 October 2013. First published online 13 May 2014. the rise in corporate signatories to the United Nations Global Compact (2012) from its initiation in 2000 to $>7,000$ companies in 2012. Pre-eminent among such goals are those of no net loss (NNL) or net positive impact (NPI) on biodiversity, or similar wording (hereafter collectively referred to as NNL/NPI). BBOP (2012a) describes these terms as follows: 'No net loss is a target for a development project in which the impacts on biodiversity caused by the project are balanced or outweighed by measures taken to avoid and minimize the project's impacts, to undertake on-site rehabilitation/restoration, and finally to offset the residual impacts, so that no overall biodiversity loss results. Where the gain exceeds the loss, the term "net gain" [or net positive impact] may be used instead of no net loss'. Where offsets are required, these approaches are also sometimes referred to as 'compensatory mitigation'.

We review the growth and scale of corporate NNL/NPI goals, identify weaknesses, and outline key components of such goals. By identifying such components that are likely to have a demonstrable and measurable impact on biodiversity, we seek to encourage companies to set such goals and to increase the effectiveness of these goals.

The 1992 Earth Summit in Rio de Janeiro stimulated major interest in the concept of sustainable development, and the Convention on Biological Diversity has subsequently played a key role in framing standards for corporate environmental accountability (Morgera, 2012). A free market reacts most swiftly, however, to clear financial incentives. Landmark studies by Costanza et al. (1997), Stern (2006) and TEEB (2010) made major advances in estimating financial values of ecosystem services and costs of environmental crises. Companies increasingly see a business case for improved corporate social responsibility, including management of environmental impacts (Robinson, 2012), although not all shareholders have the same view (FisherVanden \& Thorburn, 2011). PWC (2010) and Hanson et al. (2012) identified drivers of risks to business from ineffective environmental management, and of opportunities from effective management (Table 1). Each of these risks and opportunities has financial consequences, and these can provide the financial incentives to set environmental goals.

Regulatory and financial drivers that incentivize companies to define NNL/NPI goals have increased noticeably in frequency and prominence. The concept of no net loss to biodiversity first rose to prominence with its adoption as a 
TABLE 1 Major drivers of environmental opportunity and risk for companies (PWC, 2010; Hanson et al., 2012).

\begin{tabular}{|c|c|c|}
\hline $\begin{array}{l}\text { Category (from } \\
\text { Hanson et al., 2012) }\end{array}$ & Opportunity & Risk \\
\hline Operational & Ecosystem services to support operations & $\begin{array}{l}\text { Reduced productivity; scarcity \& increased cost } \\
\text { of resources; operational \& supply chain disruption }\end{array}$ \\
\hline Regulatory \& legal & $\begin{array}{l}\text { Leadership with governments to help shape } \\
\text { policies \& regulations }\end{array}$ & Fines \& project delays; liability for biodiversity impacts \\
\hline Reputational & $\begin{array}{l}\text { Preferred operator status; improved quotas; } \\
\text { staff loyalty }\end{array}$ & $\begin{array}{l}\text { Loss of 'social licence to operate': restricted access to } \\
\text { land \& resources }\end{array}$ \\
\hline Market \& product & $\begin{array}{l}\text { Brand differentiation; increased profit margins; } \\
\text { compliance with purchaser policies }\end{array}$ & Damage to brand; boycotts \\
\hline Financing & Access to finance & Reduced finance opportunities; reduced credit quality \\
\hline
\end{tabular}

project-level policy goal in the United States Clean Water Act (1977). Madsen et al. (2011) identified 45 existing compensatory mitigation programmes around the world, many underpinned by government policies or regulations. Such compensatory mitigation, or biodiversity offsetting, is a key element of achieving NNL/NPI (IAIA, 2005).

Corporate environmental goals have been encouraged by the International Finance Corporation Performance Standard 6 (IFC, 2012), which is one of the most influential environmental safeguards in finance (Morgera, 2012). The latest Standard requires private sector projects that receive investment to achieve no net loss of biodiversity in areas of natural habitat, where feasible, and net gains of biodiversity for which 'critical habitat' is designated (IFC, 2012). These high standards of environmental management outlined in Performance Standard 6 are being followed, for project finance of $\geq$ USD 10 million, by over 75 major financial institutions through their adoption of the Equator Principles (2012). Environmental management is thus no longer seen as a peripheral part of corporate social responsibility but as an integral part of the 'credit risk management framework for determining, assessing and managing environmental and social risk in project finance transactions' (Equator Principles, 2012).

\section{Methods}

Although we use the phrase NNL/NPI goals for convenience, terminology used to describe equivalent goals varies widely (BBOP, 2012b). We identified corporate NNL/NPI goals by searching Google (2012) for a variety of key terms, broad enough to ensure retrieval of as many NNL/NPI goals as possible. These terms were selected based on phrases in key multi-stakeholder initiatives, international standards and other sources (e.g. ICMM, 2006; BBOP, 2012b; IFC, 2012). Key terms, in English only, were combined to generate phrases for search queries (Supplementary Table S1). Searches were carried out during March-June 2012. Goals made after 31 December 2011 were excluded in order to include only whole years and to allow adequate time for decisions to be publicized on websites and indexed by search engines. We found only two companies with NNL/NPI goals published later, although more may exist: Kingfisher plc from 2012, and BG Group plc from 2013.

Although many goals exist at project-, product- or brand-level, we aimed to assess high-level corporate goals. We thus excluded goals of entities that are joint ventures (e.g. Nokia Siemens Networks B.V. and Midland Quarry Products Limited), or divisions or subsidiaries of parent companies (e.g. CEMEX UK Operations Limited, Huber Engineered Materials and Winstone Aggregates) or combinations of the above, some of which may be pilot sites.

To increase retrieval of NNL/NPI goals, searches continued until five consecutive web pages (with 10 results per page) returned no positive results. This was a threshold beyond which we believe the chance of further positive results was minimal but was ultimately an arbitrary threshold. Search results have inherent bias towards larger companies, with websites that usually score higher in Google (2012) searches, and away from companies without Englishlanguage websites. We believe, however, that the search was thorough enough to have identified all or most major corporate NNL/NPI goals. The search was comprehensive enough to identify our key target: trends in declaration of such goals.

To identify growth in NNL/NPI goals over time we identified their publication dates based on the following hierarchy: (1) dates available online, (2) if dates were unavailable or unclear online, through direct contact with companies, or (3) if this did not provide confirmation, we estimated dates from when documents were written or when documents were posted.

We also qualitatively assessed which of the goals may actually lead to measurable positive outcomes for biodiversity. We first identified such goals as those having explicit inclusion of biodiversity (including habitats and species), rather than general references such as those to the environment, greenhouse gas emissions or water use. Furthermore, through our experience of supporting corporate biodiversity 
management and from relevant literature, we identified key components of NNL/NPI goals that are most likely to ensure the effectiveness of these goals in both benefiting biodiversity and managing business risk. This assessment was necessarily qualitative, given a lack of comparable data on implementation of corporate NNL/NPI goals.

\section{Results}

We identified 32 companies that have set public, companywide, environmental NNL/NPI goals (Table 2). The earliest goal we identified was by Solid Energy, a coal-focused energy company, in 2001: 'achieving a positive net effect on the New Zealand environment across all our businesses' (Solid Energy, 2004). Since then, there has been a marked rise in the number of companies making NNL/NPI goals, including eight additional companies in 2010 alone (Fig. 1).

Mining companies (including aggregates, minerals, metals and coal mining) have set the most NNL/NPI goals: 13 of 32 (41\%: Fig. 1, Table 2). Energy and manufacturing companies are the next largest contributors, with five and four companies each, respectively (16 and $13 \%$ : Table 2). The nine other companies with NNL/NPI goals occupy sectors as diverse as entertainment, retail and pearl farming (Table 2). The proportion of companies with NNL/NPI goals that are mining companies has also increased over time, from $25 \%$ in 2006 (three companies) to $42 \%$ in 2011 (13 companies; Fig. 1). Despite the prevalence of NNL/NPI goals set by mining companies, none were found to be set by oil and gas companies, the other major extractive industry, up to 2011. Since then, however, BG Group plc has set a public NNL/NPI biodiversity goal.

Of the 32 companies with NNL/NPI goals, 18 have explicitly included biodiversity, of which 12 were from the mining sector (Table 2). Integration of certain key components within these biodiversity-focused NNL/NPI goals is most likely to ensure their effectiveness in both benefiting biodiversity and managing business risk (Table 3). No company goal contained all seven of the key components described in Table 3. Mining company goals contained proportionately more key components than did those of other companies: they made up $63 \%$ of the companies that had the majority (4-6) of the key components but only $29 \%$ of the companies with a small number (1-3) of components.

\section{Discussion}

Management of negative corporate impacts has immense potential for biodiversity conservation, owing to the key role corporate activity plays in biodiversity loss, the large spatial and long temporal scales at which companies operate, their political weight, extensive landholdings and resources (Robinson, 2011; Houdet et al., 2012). This potential has, however, been far from realized to date (Robinson, 2012).
Overall, the number of companies explicitly aiming to achieve NNL/NPI remains small but is growing rapidly and includes six of the world's largest 500 companies by revenue (Fortune, 2012).

The actual nature of corporate NNL/NPI goals at present varies greatly. Some are just vague environmental statements that appear to be pure public relations exercises (Slack, 2012). Others are carefully worded goals that incorporate many of the components identified in Table 3. These components, from our experience and the judgement of other authors, increase the effectiveness of these goals for benefiting biodiversity and managing business risk (e.g. Solid Energy, 2004; Rio Tinto, 2008). These components can ensure that goals are measurable and verifiable. Biodiversity goals are conventionally seen to involve trade-offs between benefits to biodiversity and managing business risk. However, this is changing because stakeholders are increasingly imposing costs (e.g. fines, project delays, lawsuits) on companies for biodiversity impacts; i.e. incorporating environmental externalities as real costs. The business case has therefore become stronger. There is much potential for improvement of current and future goals to ensure they include all of the key components described in Table 3.

The NNL/NPI concept has gained more traction in some industries than others. The current preponderance of mining companies with NNL/NPI goals is not reflective of a greater overall impact of the mining industry on biodiversity. Agriculture and logging, for example, both present much greater threats to both threatened and non-threatened species than extractive industry: data from the IUCN Red List show that agriculture and logging threaten 11,505 and 10,419 species, respectively, including $>5,000$ threatened species each, whereas extractive industry threatens 2,698 species, of which 1,293 are already categorized as threatened (IUCN, 2012). Agriculture and logging therefore threaten more than three times as many species as mining.

Management of biodiversity in the agriculture and logging industries has been driven by certification programmes rather than NNL/NPI goals (Laurance et al., 2010; Edwards \& Laurance, 2012). Some of these programmes are well developed but those without NNL/NPI elements fail to reach their full potential to safeguard biodiversity (UNEPWCMC, 2011). Our experience suggests that the dominance of mining companies among those with NNL/NPI goals can be explained by three main factors. Firstly, mining companies have actively participated in best practice bodies; e.g. the Business and Biodiversity Offsets Programme and International Council on Mining and Minerals, which foster peer group development of practices that improve corporate reputation and marketing. Secondly, mining companies have impacts with a high global profile (oil and gas companies, by contrast, have risks with a high global profile, which they traditionally manage differently to impacts). Thirdly, mining companies have relatively high net 
TABLE 2 Companies with public, company-wide NNL/NPI goals, as identified using search terms, up to 31 December 2011.

\begin{tabular}{|c|c|c|c|c|c|}
\hline Company & Date & Industry type & $\begin{array}{l}\text { Multi-stakeholder } \\
\text { initiative membership }\end{array}$ & $\begin{array}{l}\text { Specific biodiversity } \\
\text { goal }\end{array}$ & NNL/NPI goal phrase \\
\hline Solid Energy New Zealand Ltd & 2001 & Mining & BBOP & Yes & Positive net effect on ecosystems \\
\hline Wood Joiners & 2003 & Construction & & No & Positive impact on our environment \\
\hline Rio Tinto Group & 2004 & Mining & ICMM & Yes & Net positive impact on biodiversity \\
\hline British Columbia Hydro \& Power Authority & 2004 & Energy & & No & No net incremental environmental impact \\
\hline Comet Skateboards & 2004 & Manufacturing & & No & Net positive impact on the environment \\
\hline Hayleys Group & 2004 & Trading & & No & Environmental neutrality \\
\hline Advanced Glazings Ltd & 2005 & Manufacturing & & No & Net positive impact on the environment \\
\hline Lonmin Plc & 2005 & Mining & ICMM & Yes & Zero harm to the environment \\
\hline Wal-Mart Stores, Inc. & 2005 & Retail & & Yes & Acre for acre \\
\hline Interface, Inc. & 2006 & Manufacturing & & No & No negative impacts on the environment \\
\hline Just Drinking Water Ltd & 2006 & Food & & No & Net positive impact on our planet \\
\hline Willie Creek Pearls Group & 2006 & Pearls & & No & No negative impact on the natural environment \\
\hline Xstrata plc & 2007 & Mining & ICMM & Yes & Avoid net losses...of natural habitats, biodiversity \\
\hline Energias de Portugal Group & 2007 & Energy & & Yes & Overall positive balance [on biodiversity] \\
\hline Greenko Group & 2008 & Energy & & No & Positive net effect on environmental well-being \\
\hline Walt Disney Company & 2008 & Entertainment & & Yes & Net positive impact on ecosystems \\
\hline Inmet Mining Corporation & 2008 & Mining & BBOP \& ICMM & Yes & No net loss... of biodiversity \\
\hline Becker Underwood & 2008 & Chemicals & & No & Overall positive impact on the environment \\
\hline Orlen Group & 2008 & Energy & & No & Maximum ecological neutrality \\
\hline Barrick Gold Corporation & 2009 & Mining & ICMM & Yes & No net loss to biodiversity \\
\hline Enbridge Inc. & 2009 & Energy & & Yes & Neutral [environmental] footprint \\
\hline Balfour Beatty plc & 2009 & Aggregates & & Yes & Net ecological gain \\
\hline GSky Plant Systems Inc. & 2010 & Construction & & No & Net positive impact on the environment \\
\hline Sony Corporation & 2010 & Manufacturing & & Yes & Zero environmental footprint \\
\hline Kalindee Rail Nirman (Engineers) Ltd & 2010 & Engineering & & No & Net positive impact on the environment \\
\hline De Beers Group & 2010 & Mining & & Yes & No net loss of biodiversity \\
\hline Teck Resources Limited & 2010 & Mining & ICMM & Yes & Net positive impact on biodiversity \\
\hline Tom Farms LLC & 2010 & Chemicals & & Yes & Net benefit for...the environment \\
\hline Lundin Mining Corporation & 2010 & Mining & & Yes & Avoid net losses... of natural habitat \\
\hline Eco Oro Ltd & 2010 & Mining & & Yes & No net loss of biodiversity \\
\hline General Moly, Inc. & 2010 & Mining & & No & Positive impact on the environment \\
\hline Norsk Hydro ASA & 2011 & Mining & ICMM & Yes & No net loss to biodiversity \\
\hline
\end{tabular}

${ }^{\star}$ BBOP, Business and Biodiversity Offsets Programme; ICMM, International Council on Mining and Minerals 
TABLE 3 Components of NNL/NPI goals that are likely to increase their effectiveness in benefiting biodiversity and managing business risk, based on our experience and relevant literature.

\begin{tabular}{|c|c|}
\hline Components & Justification \\
\hline $\begin{array}{l}\text { Defined biodiversity } \\
\text { scope }\end{array}$ & $\begin{array}{l}\text { Specification of which biodiversity is included, rather than a general mention of 'biodiversity' or 'environment' } \\
\text { will focus efforts, increase transparency \& improve achievability \& measurability (Robinson, 1993; BBOP, 2012b). } \\
\text { Included biodiversity should encompass both global \& local conservation priorities (IFC, 2012). }\end{array}$ \\
\hline Defined impact scope & $\begin{array}{l}\text { Specification of which impacts are included will also focus efforts, increase transparency \& improve achievability } \\
\text { \& measurability. As such, goals should ideally address direct, indirect \& cumulative impacts. Goals may only } \\
\text { include certain types of project or finance; e.g. project finance of USD } 10 \text { million or more (Equator Principles, } \\
\text { 2012). Goals may retrospectively include existing projects or apply solely to future projects. }\end{array}$ \\
\hline Measurable goal & $\begin{array}{l}\text { By definition, goals must be measurable in order that the progress towards NNL/NPI can be tracked (BBOP, } \\
\text { 2012b; Gardner et al., 2013). }\end{array}$ \\
\hline Mitigation hierarchy & $\begin{array}{l}\text { Following the mitigation hierarchy (avoidance \& minimization of impacts, followed by restoration/rehabilitation, } \\
\text { \& finally offsets) will optimize reduction of biodiversity impacts \& minimize costs (McKenney \& Kiesecker, 2010; } \\
\text { Quintero \& Mathur, 2011; BBOP, 2012b). Each section of the mitigation hierarchy should be addressed. }\end{array}$ \\
\hline $\begin{array}{l}\text { Upper limits } \\
\text { to impacts }\end{array}$ & $\begin{array}{l}\text { NNL/NPI cannot always be achieved: some impacts cannot be offset (BBOP, 2012b; Pilgrim et al., 2013). Goals } \\
\text { should acknowledge these upper limits by explicitly outlining impacts that will be wholly avoided; e.g. goals not to } \\
\text { develop mines in World Heritage sites (Athanas, 2005). }\end{array}$ \\
\hline $\begin{array}{l}\text { Appropriate } \\
\text { timeframe }\end{array}$ & $\begin{array}{l}\text { An explicit timeframe for achievement of goals will help management of stakeholder \& biodiversity risks } \\
\text { (McKenney \& Kiesecker, 2010; IFC, 2012; Pilgrim et al., 2013). Earlier action will reduce the risk \& costs (Martin } \\
\text { et al., 2012). Such a timeframe will have to be determined on a case-by-case basis linked to the ecology of } \\
\text { individual species (IFC, 2012); e.g. within a generation or migration cycle; within } 5 \text { years. }\end{array}$ \\
\hline Transparency & $\begin{array}{l}\text { Clear, public disclosure of goals, \& progress towards them, optimizes building of stakeholder trust \& avoids } \\
\text { accusations of 'green-wash' (ICMM, 2010; TEEB, 2010; UNEP-WCMC, 2011; Robinson, 2012). Ideally, disclosed } \\
\text { information would be verified by independent third-parties (TEEB, 2010). Reporting could include making data } \\
\text { available on target species or habitats. }\end{array}$ \\
\hline
\end{tabular}

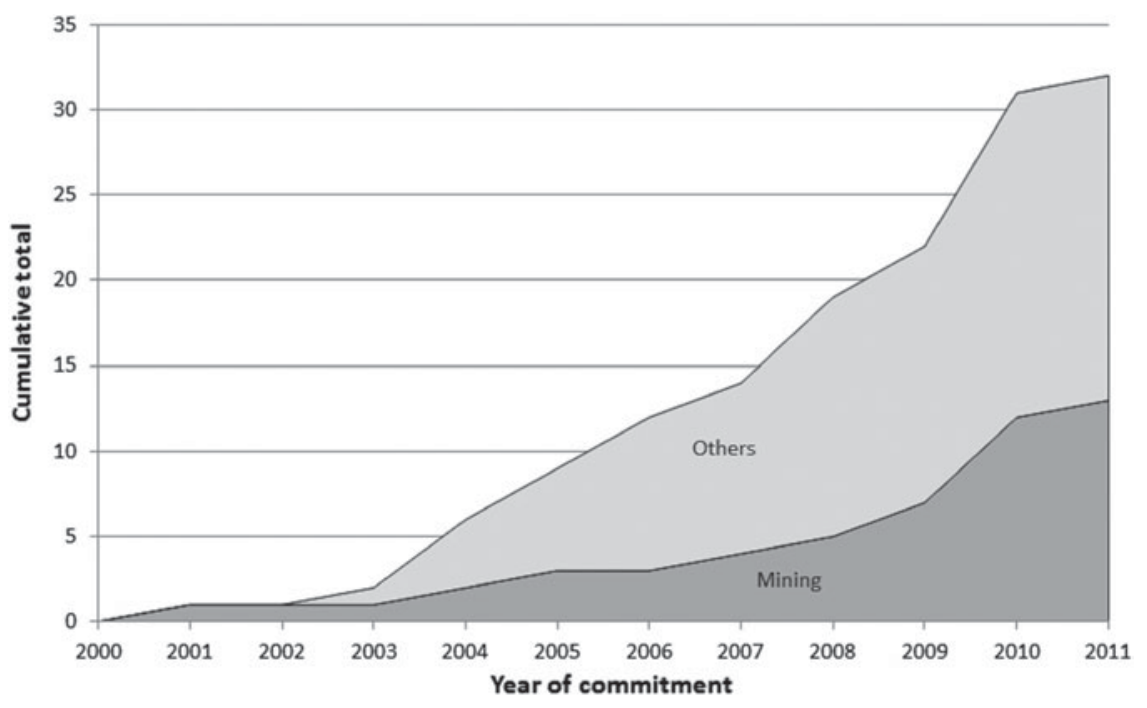

FIG. 1 Growth in number of companywide, public NNL/NPI goals over time. The mining sector has set the greatest number of NNL/NPI goals. economic profits per area of impact (compared, for example, to agriculture, which has a small profit margin per area of impact), allowing them to aim for positive impacts rather than just reducing negative impacts.

Environmental regulations in developed countries have increasingly incorporated NNL/NPI concepts (McKenney \& Kiesecker, 2010; Madsen et al., 2011), although they may not yet be delivering NNL/NPI (McKenney \& Kiesecker,
2010; Maron et al., 2012). Many non-OECD countries do not currently have such well-developed regulations, and existing social and environmental impact assessment regulations are often not effective in mitigating impacts on biodiversity (Hill \& Arnold, 2012). Unless Equator Principle (2012) or multilateral bank financing is involved, voluntary best practice will therefore be necessary to manage corporate biodiversity impacts in these countries, as well as in 
unconventional environments and where regulations have not kept pace with novel industrial practices (Schindler \& Lee, 2010; Ramirez-Llodra et al., 2011).

At present, most corporate NNL/NPI goals have advanced little beyond definition. If they are also implemented, they can be used as a voluntary drive for organizational change in a positive way, much as 'zero harm' targets have improved corporate health and safety policy and implementation (Gunningham, 2007). NNL/NPI goals aim to benefit biodiversity and manage stakeholder risk and therefore improve financial performance. To do so, they require effective definition (Table 3 ) and implementation, tasks in which the scientific and conservation communities can play a key role through engagement with companies (Gardner et al., 2013; Pedroni et al., 2013). Committed regulators, whether governments or financial institutions, are also essential to ensuring effective implementation (Bull et al., 2013; Gardner et al., 2013). Intransigent problems mean that no net loss and net positive impact may ultimately be unachievable goals (Walker et al., 2009), and engagement with companies is not the sole answer to biodiversity conservation (Robinson, 2012). Nonetheless, effective implementation of well-defined NNL/NPI goals could do much to shift the current business paradigm of 'reducing harm' towards that of 'positive impact' on biodiversity (Warhurst, 2001).

\section{Acknowledgements}

Annelisa Grigg and two anonymous referees provided helpful comments. We thank Charmila De Silva, Andrew Miles, Mark Pizey, Jason Salfi and Michael Yaker for useful information regarding corporate environmental goals. Rio Tinto supported an early draft of this article but has not influenced its content: the views expressed are those of the authors.

\section{References}

Athanas, A. (2005) The role of business in biodiversity and impact assessment. Impact Assessment and Project Appraisal, 23, 29-35.

BBOP (Business and Biodiversity Offsets Programme) (2012a) Guidance Notes to the Standard on Biodiversity Offsets. Business and Biodiversity Offsets Programme, Washington, DC, USA.

BBOP (Business and Biodiversity Offsets Programme) (2012b) Resource Paper: No Net Loss and Loss-Gain Calculations in Biodiversity Offsets. Business and Biodiversity Offsets Programme, Washington, DC, USA.

Bull, J.W., Suttle, K.B., Gordon, A., Singh, N.J. \& Milner-Gulland, E.J. (2013) Biodiversity offsets in theory and practice. Oryx, 47, 369-380.

Costanza, R., D’Arge, R., de Groot, R., Farber, S., Grasso, M., Hannon, B. et al. (1997) The value of the world's ecosystem services and natural capital. Nature, 387, 253-260.

Edwards, D.P. \& Laurance, S.G. (2012) Green labelling, sustainability and the expansion of tropical agriculture: critical issues for certification schemes. Biological Conservation, $151,60-64$.

Equator Principles (2012) Equator Principles. Http://www.equatorprinciples.com/ [accessed 24 October 2012].

Fisher-Vanden, K. \& Thorburn, K.S. (2011) Voluntary corporate environmental initiatives and shareholder wealth. Journal of Environmental Economics and Management, 62, 430-445.

Fortune (2012) Fortune Global 500 companies. Fortune, 23 July 2012. Http://money.cnn.com/magazines/fortune/global500/2012/full_list/ [accessed 30 November 2012].

Gardner, T.A., von Hase, A., Brownlie, S., Ekstrom, J.M.M., Pilgrim, J.D., SAVY, C.E. et al. (2013) Biodiversity offsets and the challenge of achieving no net loss. Conservation Biology, 27, 1254-1264.

Google (2012) Http://www.google.co.uk [accessed 1 March-30 June 2012].

Gunningham, N. (2007) Mine Safety: Law Regulation Policy. Federation Press, Annandale, Australia.

Hanson, C., Ranganathan, J., Iceland, C. \& Finisdore, J. (2012) The Corporate Ecosystem Services Review: Guidelines for Identifying Business Risks and Opportunities Arising from Ecosystem Change. Version 2.o. World Resources Institute, Washington, DC, USA.

Hill, D. \& ARnold, R. (2012) Building the evidence base for ecological impact assessment and mitigation. Journal of Applied Ecology, 49, 6-9.

Houdet, J., Tommetter, M. \& Weber, J. (2012) Understanding changes in business strategies regarding biodiversity and ecosystem services. Ecological Economics, 73, 37-46.

iaiA (International Association for Impact Assessment) (2005) Biodiversity in Impact Assessment. Special Publication Series No. 3. International Association for Impact Assessment, Fargo, USA.

iCMM (International Council on Mining and Minerals) (2006) Good Practice Guidance for Mining and Biodiversity. International Council on Mining and Minerals, London, UK.

iCMm (International Council on Mining and Minerals) (2010) Mining and Biodiversity: A Collection of Case Studies. International Council on Mining and Minerals, London, UK.

IFC (International Finance Corporation) (2012) Performance Standard 6. Biodiversity Conservation and Sustainable Management of Natural Resources. January 1, 2012. International Finance Corporation, Washington, DC, USA. Http://www1.ifc.org/wps/wcm/connect/Topics_Ext_Content/ IFC_External_Corporate_Site/IFC+Sustainability/Sustainability +Framework/Sustainability+Framework+-+2012/Performance +Standards+and+Guidance+Notes+2012/ [accessed 10 May 2012].

IUCN (2012) IUCN Red List of Threatened Species v. 2012.1. Http:// www.iucnredlist.org/ [accessed 3 October 2012].

Laurance, W.F., Koh, L.P., Butler, R., Sodhi, N.S., Bradshaw, C. J.A., NeIdeL, J.D. et al. (2010) Improving the performance of the Roundtable on Sustainable Palm Oil for nature conservation. Conservation Biology, 24, 377-381.

Lavallée, S. \& Plouffe, S. (2004) The ecolabel and sustainable development. The International Journal of Life Cycle Assessment, 9, 349-354.

Madsen, B., Carroll, N., Kandy, D. \& Bennett, G. (2011) Update: State of Biodiversity Markets. Forest Trends, Washington, DC, USA. Http://www.forest-trends.org/documents/files/doc_2848. pdf [accessed 3 June 2012].

Maron, M., Hobbs, R.J., Mollanen, A., Matthews, J.W., Christie, K., Gardner, T.A. et al. (2012) Faustian bargains? Restoration realities in the context of biodiversity offset policies. Biological Conservation, 155, 141-148. 
Martin, T.G., Nally, S., Burbridge, A.A., Arnall, S., Garnett, S.T., Hayward, M.W. et al. (2012) Acting fast helps avoid extinction. Conservation Letters, 5, 274-280.

McKenney, B.A. \& Kiesecker, J.M. (2010) Policy development for biodiversity offsets: a review of offset frameworks. Environmental Management, 45, 165-176.

Morgera, E. (2012) From Corporate Social Responsibility to Accountability Mechanisms: The Role of the Convention on Biological Diversity. Edinburgh School of Law Research Paper Series. University of Edinburgh, UK.

Pedroni, P.M., Jaramillo, H., Torres, C.M. de L., Navarrete, Z.H., Bernal-Ramirez, J. \& Reed, T. (2013) A partnership approach to addressing applied ecological research needs of an oil and gas business. Journal of Applied Ecology, 50, 539-543.

Pilgrim, J.D., Brownlie, S., Ekstrom, J.M.M., Gardner, T.A., von Hase, A., ten Kate, K. et al. (2013) A process for assessing offsetability of biodiversity impacts. Conservation Letters, 6 , $376-384$.

PWC (PricewaterhouseCoopers) (2010) Biodiversity and Business Risk. PWC, London, UK, and World Economic Forum, Geneva, Switzerland.

Quintero, J.D. \& Mathur, A. (2011) Biodiversity offsets and infrastructure. Conservation Biology, 25, 1121-1123.

Ramirez-Llodra, E., Tyler, P.A., Baker, M.C., Bergstad, O.A., Clark, M.R., Elva, E. et al. (2011) Man and the last great wilderness: human impact on the deep sea. PLoS ONE, 6(8), e22588.

Rio Tinto (2008) Rio Tinto and Biodiversity. Rio Tinto, London, UK.

Robinson, J.G. (1993) The limits to caring: sustainable living and the loss of biodiversity. Conservation Biology, 7, 20-28.

Robinson, J.G. (2011) Corporate greening: is it significant for biodiversity conservation? Oryx, 45, 309-310.

Robinson, J.G. (2012) Common and conflicting interests in the engagements between conservation organizations and corporations. Conservation Biology, 26, 967-977.

Schindler, D.W. \& Lee, P.G. (2010) Comprehensive conservation planning to protect biodiversity and ecosystem services in Canadian boreal regions under a warming climate and increasing exploitation. Biological Conservation, 143, 1571-1586.

SLACK, K. (2012) Mission impossible?: adopting a CSR-based business model for extractive industries in developing countries. Resources Policy, 37, 179-184.
Solid Energy (2004) Environmental Policy Statement. Solid Energy, Christchurch, New Zealand.

Stern, D. (2006) Stern Review on the Economics of Climate Change. HM Treasury, Cambridge University Press, Cambridge, UK.

TEEB (The Economics of Ecosystems and Biodiversity) (2010) The Economics of Ecosystems and Biodiversity: Mainstreaming the Economics of Nature: A Synthesis of the Approach, Conclusions and Recommendations of TEEB. Http://www.teebweb.org/publication/mainstreaming-theeconomics-of-nature-a-synthesis-of-the-approach-conclusionsand-recommendations-of-teeb/ [accessed 10 May 2012].

UNEP-WCMC (2011) Review of the Biodiversity Requirements of Standards and Certification Schemes: A Snapshot of Current Practices. Technical Series No. 63. Secretariat of the Convention on Biological Diversity, Montreal, Canada.

United Nations Global Compact (2012) The Ten Principles of the United Nations Global Compact. Http://www.unglobalcompact.org/ AboutTheGC/TheTenPrinciples/index.html [accessed 1o December 2012].

Walker, S., Brower, A.L., Stephens, R.T.T. \& Lee, W.G. (2009) Why bartering biodiversity fails. Conservation Letters, 2, 149-157.

Warhurst, A. (2001) Corporate citizenship and corporate social investment. Journal of Corporate Citizenship, 1, 57-73.

\section{Biographical sketches}

Hugo J. Rainey has a particular interest in protected area management in Africa and South-east Asia, specializing in bird and mammal conservation and monitoring. EdWARd H.B. Pollard focuses on protected areas and sustainable forest management in Africa and South-east Asia. Gu y D U T son has been leading fieldwork, research and conservation projects across Asia, the Pacific and Africa for 25 years and wrote The Birds of Melanesia. Jonathan M.M. ЕКSтRом concentrates on cross-sector partnerships among industry, academia and conservation organizations. Suzanne R. Livingstone has particular expertise on marine turtles, and marine conservation more broadly. HELEN J. TEMPLE's work ranges from research and management of threatened species in the field to analyses of status and trends of global biodiversity. JOHN D. PILGRIM focuses on the application of conservation planning, priority-setting and monitoring theory to improve conservation practice. 